\title{
MIĘDZYNARODOWE ŚRODOWISKO BEZPIECZEŃSTWA AZJI WSCHODNIEJ W 2016 ROKU. ZASADNICZE DETERMINANTY I KIERUNKI EWOLUCJI
}

Rok 2016 przyniósł liczne wydarzenia międzynarodowe o doniosłym znaczeniu dla ewolucji stanu i percepcji bezpieczeństwa międzynarodowego. Zarówno na poziomie globalnym, jak i regionalnym ewolucja międzynarodowego środowiska bezpieczeństwa nabrała nowej dynamiki. Można zaryzykować twierdzenie, iż obserwujemy obecnie swego rodzaju zerwanie ze względną stabilnością ładu pozimnowojennego. Wnikliwi obserwatorzy rzeczywistości międzynarodowej coraz częściej posługują się takimi pojęciami jak ,strategiczne pęknięcie” (ang. ruptures stratégiques; Heisbourg, 2013: 12) czy „dryfujący świat” (franc. world adrift; Crocker, 2015: 7).

Celem tego artykułu jest analiza stanu międzynarodowego środowiska bezpieczeństwa regionu Azji Wschodniej oraz zasadniczych kierunków jego ewolucji w roku 2016. Dla jego osiagnięcia konieczne jest odniesienie się do trzech zasadniczych kwestii. Po pierwsze, niezbędna jest identyfikacja kluczowych trendów długoterminowych kształtujących regionalny ład bezpieczeństwa omawianego obszaru. Dzięki temu możliwe będzie określenie „stanu wyjściowego" regionu na początku analizowanego okresu, a także określenie swoistego „łła strategicznego”, w odniesieniu do którego należy rozpatrywać bieżące wydarzenia. Następnie autor przedstawi kluczowe wydarzenia z obszaru bezpieczeństwa międzynarodowego, które zaszły w Azji Wschodniej w trakcie 2016 r. (oraz w pierwszych miesiącach 2017) i umieści je w nakreślonym kontekście strategicznym. Na tym etapie możliwe będzie sformułowanie wstępnej oceny co do wpływu pojedynczych wydarzeń na międzynarodowe środowisko bezpieczeństwa regionu (stabilizujące, destabilizujące lub neutralne). W ostatnim etapie, na bazie dotychczasowych rozważań zostanie podjęta próba prognozy dalszej ewolucji sytuacji bezpieczeństwa w Azji Wschodniej w perspektywie kolejnych 12-18 miesięcy.

\section{TŁO STRATEGICZNE REGIONU}

Region Azji Wschodniej obejmuje zasadniczo obszar wybrzeży Basenu Zachodniego Pacyfiku. W jego skład klasycznie zalicza się następujące państwa i terytoria: Rosyjski Daleki Wschód, Japonię, Koreańską Republikę Ludowo-Demokratyczną, Republikę Korei, Chińską Republikę Ludową, Republikę Chińską (Tajwan), Mongolię oraz państwa członkowskie Stowarzyszenia Narodów Azji Południowo-Wschodniej 
(ASEAN - Indonezja, Malezja, Singapur, Tajlandia, Brunei, Laos, Kambodża, Wietnam i Mjanama - chociaż to ostatnie państwo geograficznie należy do basenu Oceanu Indyjskiego) (Gawlikowski, 2004: 21). Pod względem geograficznym region ten określa jego rozległość (dla ilustracji można przytoczyć dystans dzielący miasta położone w przybliżeniu na jego północnych i południowych obrzeżach tj. Tokio-Singapur - $5321 \mathrm{~km}$; Haliżak, 1999: 53). Co istotne, jest to region o istotnym komponencie morskim. Wynika to z dominacji państw nadbrzeżnych takich akwenów, jak morza: Ochockie, Japońskie, Wschodnio- i Południowochińskie oraz otwartych wód Oceanu Spokojnego. Morska aktywność gospodarza, wojskowa i naukowa ma trudne do przecenienia znaczenie dla interakcji państw tego regionu, co wpisuje się w koncepcję regionalizmu morskiego (Haliżak, 1999: 41-50). Azja Wschodnia to także obszar o istotnym potencjale demograficznym. W roku $2016 \mathrm{w}$ nakreślonych granicach regionu mieszkało 2,247 mld ludzi, co stanowiło 30\% ogółu ludności świata (2016 World population, 2016: 10-13). Warto także zaznaczyć, iż ludność Azji Wschodniej jest silnie zróżnicowana pod względem etnicznym i religijnym (chociaż dotyczy to w większym stopniu państw ASEAN, państwa Azji Północno-Wschodniej - ChRL, RCh, Japonia, KRL-D i RK są o wiele bardziej homogeniczne pod względem etnicznym).

Państwa Azji Wschodniej reprezentują znaczną różnorodność form ustrojowych. Do grona państw demokratycznych można zaliczyć: Mongolię, Japonię, Republikę Korei, Republikę Chińską, Indonezję i Filipiny. Chińską Republikę Ludową i Koreańską Republikę Ludowo-Demokratyczną należałoby zaliczyć do osobnej kategorii państw post-totalitarnych (w przypadku KRL-D można w zasadzie mówić o niemal klasycznym totalitaryzmie). Oprócz tego mamy państwa autorytarne (Federacja Rosyjska, Wietnam, Laos, Brunei, Tajlandia - po przewrocie wojskowym 2014 r., Singapur, Kambodża) oraz państwa określane jako przypadki graniczne między demokracją a autorytaryzmem - Malezja i Mjanma.

Globalne znaczenie Azji Wschodniej jest $\mathrm{w}$ istotnym stopniu pochodną dynamizmu gospodarczego tego regionu. To właśnie ten region doświadczył tego co Bank Światowy nazwał azjatyckim cudem gospodarczym (określenie to jest uzasadnione chociażby z uwagi na to, iż państwa rozwinięte potrzebowały ok. 400 lat, aby dziesięciokrotnie zwiększyć swój dochód per capita (w latach 1400-1950), podczas gdy nowo uprzemysłowione państwa Azji Wschodniej osiagnęły porównywalny wzrost poziomu dochodu per capita w mniej niż 50 lat (Haliżak, 1999: 81). W roku 2015 szerszy region Azji Wschodniej i Pacyfiku wytwarzał ok. 29\% ogółu światowego PKB (najwyższy udział ze wszystkich regionów; World Bank, 2015). Głównym motorem tak dynamicznego rozwoju gospodarczego regionu pozostaje eksport. Dość wspomnieć, iż w Azji Wschodniej znajduje się czterech z dziesięciu największych eksporterów towarów w 2015 r. Są to Chińska Republika Ludowa (miejsce 1.), Japonia (miejsce 4.), Republika Korei (miejsce 6.) oraz Specjalny Region Autonomiczny Hong Kong (miejsce 7.). Wyżej wymienione gospodarki łącznie wyeksportowały w $2015 \mathrm{r}$. towary o wartości 3,938 bln dolarów, co stanowiło 23,9\% ogółu światowego eksportu towarowego (World Trade, 2016: 94). Azję Wschodnią charakteryzuje również istotne zróżnicowanie poziomu rozwoju społeczno-gospodarczego państw. Warto zauważyć, iż do regionu tego należy 5 z 20 największych gospodarek świata (według nominalnego PKB), a mianowicie ChRL (pozycja 2.), Japonia (3.), Republika Korei (11.), Fede- 
racja Rosyjska (13.) oraz Indonezja (16.). Spośród nich cztery wypracowały w 2015 r. PKB przekraczający bilion dolarów. Na przeciwległym biegunie znajdują się Laos (miejsce 124. - PKB ok. 12 mld USD) (Gross Domestic, 2015).

$\mathrm{Z}$ punktu widzenia bezpieczeństwa międzynarodowego, kluczowa jest również pozycja Azji Wschodniej w międzynarodowym układzie sił militarnych. W regionie tym położone są cztery z piętnastu państw o największych budżetach obronnych w $2016 \mathrm{r}$. (ChRL, Rosja, Japonia i Republika Korei). Ich łączne wydatki obronne stanowiły $22 \%$ ogółu światowych wydatków obronnych. Warto podkreślić, iż w roku 2016 wszystkie państwa Azji Wschodniej (z wyjątkiem KRL-D, odnośnie której SIPRI nie dysponuje pełnymi danymi) przeznaczyły łącznie $308 \mathrm{mld}$ dol. na obronę. Istotna jest nie tylko skala, ale i dynamika tych wydatków. W roku 2016 wzrosły one o 4,3\% w porównaniu $\mathrm{z}$ rokiem poprzednim, natomiast skumulowany wzrost regionalnych wydatków obronnych w latach 2007-2016 wyniósł 74\% (Trends in world, 2017). Nie bez znaczenia pozostaje fakt, iż spora część zapotrzebowania wschodnioazjatyckich sił zbrojnych w zakresie uzbrojenia i sprzętu wojskowego jest zaspokajana na drodze importu. Mimo intensywnego rozwoju przemysłu zbrojeniowego w regionie (przykładowo w latach 2012-2016 ChRL była trzecim największym eksporterem uzbrojenia na świecie) w latach 2012-2016 Azja i Oceania miały najwyższy spośród wszystkich regionów udział w imporcie uzbrojenia (43\%). Dodatkowo na samą Azję Wschodnią przypadało 6 z 20 największych importerów uzbrojenia w latach 2012-2016. (Trends in international, 2017). Dla układu sił w regionie istotny jest również fakt obecności na jego obszarze trzech państw dysponujących bronią jądrową (Federacja Rosyjska, ChRL i KRL-D).

Biorąc pod uwagę przedstawioną powyżej charakterystykę regionu Azji Wschodniej można określić kluczowe długoterminowe charakterystyki jego międzynarodowego środowiska bezpieczeństwa.

A) Wysoka koncentracja potencjału gospodarczego i militarnego. Przytoczone powyżej statystyki nie pozostawiają wątpliwości co do tego, iż Azja Wschodnia zawiera $\mathrm{w}$ swych granicach szereg mocarstw, w tym państwo potencjalnie zdolne do osiagnięcia statusu supermocarstwa - ChRL. Oznacza to, iż zasadniczym wyzwaniem z punktu widzenia międzynarodowego środowiska bezpieczeństwa jest nie tyle słabość struktur państwowych (która oczywiście dotyka część państw regionu - zwłaszcza w Azji Południowo-Wschodniej), co rosnąca potęga wielu graczy regionalnych i odpowiadająca temu zjawisku - asertywna polityka.

B) Niski poziom instytucjonalizacji współpracy regionalnej w dziedzinie bezpieczeństwa. W Azji Wschodniej nie funkcjonuje żadna organizacja międzynarodowa, która gromadziłaby wszystkie państwa tego obszaru i wypełniała funkcje regionalnego systemu bezpieczeństwa międzynarodowego (układ regionalny w rozumieniu rozdziału VIII KNZ, system bezpieczeństwa zbiorowego lub kooperatywnego) chociażby przez pokojowe rozstrzyganie sporów międzynarodowych lub środki budowy zaufania i bezpieczeństwa. Należy naturalnie odnotować działalność takich instytucji, jak Regionalne Forum ASEAN (ARF) czy Szczyt Wschodnioazjatycki (EAS). Jednak nie posiadają one stałych organów, ani twardych kompetencji władczych. Są to w zasadzie jedynie fora konsultacyjne. Oznacza to, iż regionalna architektura bezpieczeństwa opiera się zasadniczo na dwustronnych sojuszach polityczno-militarnych oraz polityce równowagi sił. 
C) Liczne punkty zapalne. Azja Wschodnia jest areną licznych sporów i konfliktów międzynarodowych. Te o kluczowym znaczeniu dla międzynarodowego środowiska bezpieczeństwa można by pogrupować w trzy kategorie: 1) konflikty stanowiące nierozwiązane dziedzictwo zimnej wojny - podział Korei i Chin (spór wokół statusu Tajwanu); 2) spory terytorialne (najczęściej dotyczące wysp i obszarów morskich) - do najważniejszych możemy zaliczyć: Kuryle/Terytoria Północne, Senkaku/Diaoyu, wyspy na Morzu Południowochińskim (Spratly i Paracelskie); 3) szeroko rozumianą rywalizację o przywództwo polityczno-militarne w regionie.

$\mathrm{Z}$ powyższego zestawienia jasno wynika, iż w międzynarodowym środowisku bezpieczeństwa Azji Wschodniej dominują zagrożenia i wyzwania wynikające z konfliktów miedzypaństwowych. One zatem będą głównym przedmiotem analizy w niniejszym artykule. Nie oznacza to oczywiście, iż autor nie dostrzega kwestii zagrożeń trans narodowych, jak np. terroryzm islamistyczny w Azji Południowo-Wschodniej czy toczona przez ChRL ,ludowa wojna z terroryzmem” ujgurskim (Zunyou Zhou, 2016). Jednak z uwagi na ich dominujące znaczenie tekst skupi się na problematyce relacji polityczno-militarnych między głównymi mocarstwami regionu.

\section{DEUGOTERMINOWE TRENDY KSZTALTUJĄCE MIĘDZYNARODOWE ŚRODOWISKO BEZPIECZEŃSTWA AZJI WSCHODNIEJ}

Względnie trwałe cechy nakreślonego w poprzedniej sekcji „tła strategicznego” międzynarodowego środowiska bezpieczeństwa Azji Wschodniej sprawiają, iż stan relacji między mocarstwami jest kluczową determinantą jego dalszej ewolucji. Stąd najistotniejszym, w opinii autora, długoterminowym trendem kształtującym regionalny ład bezpieczeństwa jest zmiana układu sił wynikająca z dynamicznego wzrostu potęgi Chińskiej Republiki Ludowej. Szereg analiz dotyczących ewolucji międzynarodowego układu sił (Brooks, Wohlforth, 2015; Wiśniewski, Hensarling, 2015) podkreśla, iż chociaż państwo to nie posiada jeszcze wystarczającego potencjału, aby odgrywać rolę supermocarstwa, to jednak jego pozycja w międzynarodowej hierarchii potęgi jest wyraźnie wyższa niż pozostałych państw określanych mianem ,wielkich mocarstw”. Prowadzi to do sytuacji, w której obecnie ChRL nie jest już tylko kolejnym azjatyckim mocarstwem regionalnym (jak chociażby Indie i Japonia), ale nie jest jeszcze supermocarstwem globalnym. Oznacza to jednak, iż układ sił w Azji Wschodniej jest coraz bliższy dwubiegunowości, której głównymi protagonistami są ChRL i USA.

Obecność i zaangażowanie Stanów Zjednoczonych są czynnikami, których wpływu na międzynarodowe środowisko bezpieczeństwa Azji Wschodniej nie sposób przecenić. De facto, od zakończenia II wojny światowej większość regionu żyje według reguł Pax Americana, podtrzymywanego przez amerykańską wysuniętą obecność wojskową, sieć bliskich powiązań handlowych i inwestycyjnych oraz sieć dwustronnych sojuszy polityczno-militarnych. Od czasu normalizacji relacji ChRL-USA to pierwsze państwo zdawało się akceptować amerykańskie przywództwo w regionie jako korzystne dla stabilności i rozwoju. W ostatnich dekadach widać jednak wyraźnie, iż wraz z umacnianiem się pozycji Chin w międzynarodowej hierarchii potęgi, państwo to w coraz większym stopniu kwestionuje elementy dotychczasowego ładu 
regionalnego i coraz śmielej proponuje alternatywne rozwiązania. To swoiste chińskie wyzwanie dla dotychczasowego ładu regionalnego Azji Wschodniej można dostrzec na trzech płaszczyznach: politycznej, ekonomicznej i militarnej. Na poziomie politycznej wizji ładu regionalnego władze ChRL zaprezentowały własną wizję regionalnego ładu bezpieczeństwa, zawartą w dokumencie pt. Chińska Polityka wobec wspótpracy $w$ dziedzinie bezpieczeństwa na obszarze Azji-Pacyfiku, opublikowanym w styczniu 2017 r. (China Policies, 2017). Stanowi on w pewnym sensie oficjalną wykładnię szeregu inicjatyw podejmowanych przez ChRL na forum takich instytucji, jak Szczyt Wschodnioazjatycki, Szanghajska Organizacja Współpraca czy Konferencja na temat Interakcji i Środków Budowy Zaufania w Azji. Sprowadza się ona do wizji „wspólnego, wszechstronnego, kooperatywnego i zrównoważonego bezpieczeństwa". Mimo dużej dozy ogólności i częstego powtarzania deklaracji o chęci współpracy ze wszystkimi aktorami regionalnymi zapisy tego dokumentu można traktować jako dążące do rewizji przynajmniej niektórych elementów obecnego ładu bezpieczeństwa regionu. Wielokrotnie podkreśla się nieadekwatność ,zimonowojennego myślenia” oraz „opartych na historii sojuszy". Uwagi te są ewidentnie wymierzone w sieć amerykańskich sojuszy wojskowych zawiązanych w okresie zimnej wojny stanowiących fundament amerykańskiej pozycji lidera regionalnego ładu bezpieczeństwa. Chińska propozycja nowej organizacji bezpieczeństwa na obszarze Azji i Pacyfiku, mówi także o tym, iż ,główne państwa powinny traktować strategiczne intencje innych w obiektywny i racjonalny sposób, odrzucić zimnowojenną mentalność, szanować legalne interesy i obawy innych, wzmacniać pozytywne interakcje i odpowiadać na wyzwania za pomocą skoordynowanych działań" (ibid.). Biorąc pod uwagę kontekst aktualnego stanu stosunków między mocarstwami w regionie, można to uznać za wezwanie do ograniczenia skali i ambicji amerykańskiego zaangażowania $\mathrm{w}$ regionie oraz pozostawienia państwom azjatyckim większej swobody regulowania własnych relacji (bez udziału światowego supermocarstwa). W kontekst ten wpisuje się także ponawiane wezwanie do rozstrzygania sporów terytorialnych na drodze bezpośrednich negocjacji między stronami, co w naturalny sposób wzmacnia pozycję przetargową silniejszego aktora.

Kolejną płaszczyzną, na której ChRL podejmuje aktywne działania jest regionalna współpraca i integracja gospodarcza. Sztandarowym projektem jest tu Inicjatywa Jednego Pasa i Jednej Drogi zmierzająca do budowy powiązań infrastrukturalnych, handlowych, a z czasem także więzi integracyjnych między Chinami a szerokim wachlarzem państw Eurazji. Przedsięwzięciami komplementarnymi wobec Jednego Pasa i Jednej Drogi (OBOR) są także utworzenie Azjatyckiego Banku Inwestycji Infrastrukturalnych (AIIB) czy propozycje utworzenia regionalnych porozumień handlowych jak Regionalne Wszechstronne Partnerstwo Gospodarcze (RCEP). Wszystkie te inicjatywy mają inkluzywny charakter i zmierzają do wykorzystania oraz wzmocnienia procesów regionalizacji gospodarczej zachodzących na obszarze Azji Wschodniej, jak również szerszej Eurazji. Należy jednak również zauważyć, iż służą one chińskim interesom geoekonomicznym i geopolitycznym. Ich pełna realizacja może pozwolić na wzrost chińskiego eksportu i inwestycji, umożliwiając produktywne wykorzystanie ogromnej nadwyżki potencjału produkcyjnego i finansowego wypracowanego przez ChRL w okresie dynamicznego rozwoju. Równocześnie mogą one stanowić filary nowego regionalnego ładu gospodarczego, którego centrum stanowiłyby Chiny. Reali- 
zacja takiego scenariusza miałaby istotne konsekwencje geopolityczne. Eurazjatycki blok gospodarczy pod przywództwem ChRL ogromnie zwiększyłby pozycję tego państwa wobec obecnego supermocarstwa. Projekty OBOR, AIIB czy RCEP są często postrzegane jako konkurencyjne wobec amerykańskich projektów handlowych takich jak TPP czy TTIP $i$ interpretowane jako element rywalizacji o pozycję czołowej światowej potęgi gospodarczej pozwalającej na ustalanie reguł międzynarodowego handlu ${ }^{1}$.

Zarysowana powyżej rywalizacja znajduje również odbicie na płaszczyźnie militarnej. Można śmiało przyjaćc, iż USA i ChRL znajdują się obecnie w stanie praktycznie otwartego wyścigu zbrojeń. Świadczy o tym stopień interakcji programów zbrojeniowych i rozwoju doktryn wojskowych obu mocarstw. Intensywna modernizacja Chińskiej Armii Ludowo-Wyzwoleńczej jest w pierwszej kolejności obliczona na uzyskanie możliwości zablokowania amerykańskiej interwencji zbrojnej w regionalnym konflikcie dotykającym żywotnych interesów Chin (np. dotyczącego Tajwanu). Z drugiej strony, dyskusja doktrynalna w siłach zbrojnych USA (której owocem jest koncepcja Bitwy Powietrzno-Morskiej, obecnie przemianowana na Połaczona Koncepcję Dostępu Operacyjnego) otwarcie odnosiła się do potencjalnego konfliktu z ChRL, którego tłem byłaby dominacja nad Zachodnim Pacyfikiem. Uosobieniem tych dążeń po stronie amerykańskiej była strategia zwrotu ku Azji zwierająca istotny komponent militarny w postaci rozmieszczenia w basenie Pacyfiku dodatkowych sił wojskowych.

Zarysowany powyżej trend długoterminowej rywalizacji chińsko-amerykańskiej określa międzynarodowe środowisko bezpieczeństwa Azji Wschodniej od co najmniej 20 lat (pewnym symbolicznym momentem przełomu mógł tu być kryzys tajwański z 1996 r.). W ostatnich latach można jednak zaobserwować, iż relacja ta staje się dominującą $w$ ramach międzynarodowego środowiska bezpieczeństwa regionu. Liczne wymienione wcześniej punkty zapalne, jak Korea, Tajwan, spory terytorialne na Morzach Wschodnio- i Południowochińskim - mimo osobnej historii i specyfiki są coraz bardziej osadzane w logice dwubiegunowej rywalizacji ChRL-USA + inne potęgi regionalne (Japonia, ASEAN). Poszczególne konflikty nie tracą oczywiście swojego osobnego charakteru, jednak w coraz większym stopniu stają się one kolejnymi polami zasadniczej rozgrywki Pekin-Waszyngton, a zasadniczym pytaniem dla ich rozstrzygnięcia staje się: Co na to USA? Co na to ChRL? Dynamikę tę dobrze widać na przykładzie Półwyspu Koreańskiego. Chociaż interesy obu głównych mocarstw na tym obszarze nie są zupełnie rozbieżne, to jednak każde posunięcie zasadniczych aktorów musi być rozpatrywane w kontekście wpływu na dwubiegunową rywalizację. W ostatnim czasie przekonała się o tym Republika Korei. Państwo to próbowało prowadzić swoistą politykę ekwidystansu wobec swojego głównego sojusznika militarnego (USA) oraz zasadniczego partnera handlowego (ChRL). Jednak w latach 2016-2017 rosnąca agresywność KRL-D doprowadziła do decyzji o rozmieszczeniu w Korei Południowej amerykańskiego systemu obrony przeciwrakietowej THAAD. Chociaż władze RK starały się usilnie przekonać ChRL, iż nie jest to ruch nieprzyjazny, to jednak reakcja Pekinu była bardzo zdecydowana (Nationalism unleashed, 2017). W podobnej sytuacji znajdują się państwa ASEAN odno-

${ }^{1}$ Szerzej na ten temat chociażby w: Dargnat, 2016; Clarke, 2016; Ferdinand, 2016; Fasslabend, 2015; Our bulldozers, 2016. 
śnie sporów na Morzu Południowochińskim. Po latach balansowania między dwoma mocarstwami, agresywna polityka ChRL wymusza jednoznaczne opowiedzenie się po jednej ze stron. Podsumowując, od kilku lat nasila się tendencja do (przynajmniej częściowego) „wchłaniania” regionalnych sporów i konfliktów przez nadrzędny antagonizm ChRL-USA + sojusznicy.

\section{KLUCZOWE WYDARZENIA 2016 ROKU I ICH WPLYW NA SYTUACJE W REGIONIE}

Za najważniejsze z punktu widzenia ewolucji międzynarodowego środowiska bezpieczeństwa Azji Wschodniej można uznać następujące wydarzenia 2016 r. (i pierwszych miesięcy roku 2017).

\section{A) Próby nuklearne i rakietowe KRL-D}

W 2016 r. Korea Północna dokonała dwóch prób jądrowych (6 stycznia i 9 września) jak również serii próbnych odpaleń rakiet balistycznych (w tym dwukrotnie $\mathrm{w}$ wersji przeznaczonej do przenoszenia przez okręty podwodne) (Sam Kim, 2017; Macias, 2016). W odpowiedzi, w marcu 2016 r. Rada Bezpieczeństwa ONZ przyjęła rezolucję $\mathrm{nr} 2270$, wprowadzającą (jak do tej pory) najostrzejsze sankcje gospodarcze wobec KRL-D. Rezolucja przewiduje poważne ograniczenie eksportu surowców mineralnych z KRL-D, istotnego źródła dochodów dla tego państwa (Resolution 2270, 2016: par. 29) oraz zobowiązywała państwa członkowskie do inspekcji wszelkich ładunków pochodzących z Korei Północnej (Resolution 2270, 2016: par. 18). Naturalnie, wydarzenia te nie stanowią nowej jakości w historii konfliktu na Półwyspie Koreańskim. KRL-D od dekad konsekwentnie rozwija swój potencjał nuklearny i rakietowy, jako gwarancję bezpieczeństwa reżimu wobec potencjalnej próby jego obalenia na drodze interwencji zewnętrznej (osobną sprawą pozostaje prawdopodobieństwo realizacji takiego scenariusza). Warto jednak zauważyć, iż zdaniem wielu ekspertów, intensywne prace badawczo-rozwojowe, wspomagane bogatym programem prób, istotnie przybliżają reżim w Pjongjangu do wejścia w posiadanie efektywnych sił odstraszania nuklearnego (Panda, 2017; By the rockets', 2016). Szczególnie niepokojące dla oponentów Korei Północnej są dwa kierunki prowadzonych w tym państwie prac - rozwój rakiety balistycznej o zasięgu międzykontynentalnym oraz morskiej rakiety balistycznej przenoszonej przez okręty podwodne. Skuteczne pozyskanie takich systemów uzbrojenia uczyniłby z KRL-D realną potęgę nuklearną, na skalę ponadregionalną. Dysponując pociskiem o odpowiednim zasięgu KRL-D mogłaby zagrozić bezpośrednio terytorium kontynentalnych Stanów Zjednoczonych, istotnie zwiększając zdolność nacisku na państwo postrzegane jako źródło głównego zagrożenia dla reżimu. Z kolei posiadanie morskiego elementu triady nuklearnej oddałoby do dyspozycji liderów Korei Północnej efektywny potencjał drugiego uderzenia. Wydarzenia 2016 r. na Półwyspie Koreańskim mają przynajmniej trzy powiązane ze sobą strategiczne implikacje: 1) jest zupełnie możliwe, iż Korea Północna znajduje się coraz bliżej pozyskania skutecz- 
nych zdolności do nuklearnego odstraszania nie tylko państw sąsiednich, ale także USA. Gdyby ta prognoza stała się rzeczywistością ogromnie wzmocniłoby to pozycję międzynarodową KRL-D i wydatnie zwiększyło bezpieczeństwo reżimu rządzącego tym państwem. Natomiast dla pozostałych aktorów regionalnych oznaczałoby to poważną komplikację sytuacji i konieczność mierzenia się z bardziej pewnym siebie reżimem; 2) im bardziej władze w Pjongjangu eskalują retorykę i działania, tym bardziej zdecydowane kroki podejmują USA, Korea Południowa i Japonia, celem zrównoważenia postrzeganego wzrostu zagrożenia. Przykładem jest rozmieszczenie baterii systemu przeciwrakietowego THAAD w Korei Południowej czy rozbudowa przez władze w Seulu „potencjału odwetowego” (Gady, 2016a); 3) reakcja USA i ich sojuszników jest postrzegana negatywnie przez ChRL, głównie dlatego, iż wzmacnia amerykański system sojuszniczy w Azji. Co ciekawe, Pekin reaguje zarówno większym naciskiem na Seul, jak i wyraźnymi próbami wywarcia presji na władze KRL-D, czego dowodem może być zgoda ChRL na nowe sankcje oraz próby przynajmniej częściowej ich implementacji.

\section{B) Wybory prezydenckie w Republice Chińskiej}

16 stycznia 2016 r. w Republice Chińskiej odbyły się wybory prezydenckie i parlamentarne. Ich przełomowy charakter wynika nie tylko z faktu zwycięstwa kandydatki Demokratycznej Partii Postępowej (DPP) Tasi Ing-Wen, ale również uzyskania przez to ugrupowanie większości w Yuanie Ustawodawczym. Po raz pierwszy w historii władza wykonawcza i ustawodawcza na Tajwanie została zdominowana przez ugrupowanie obozu zielonego (sympatyzującego z ideą niepodległości). Patrząc na długoterminowe konsekwencje, wybory 2016 r. są z jednej strony efektem i demonstracją przemian społeczno-politycznych zachodzących na Tajwanie, a z drugiej mogą stanowić początek nowego, bardziej antagonistycznego etapu w historii stosunków Pekin-Tajpej. Okres rządów poprzedniego prezydenta Republiki Chińskiej Ma Ying-jeu (z Partii Narodowej - Kuomintang, KMT) charakteryzował się bezprecedensowym zacieśnieniem relacji między obu państwami chińskimi. Przywrócono bezpośrednie połączenia transportowe i komunikacyjne, jak również podpisano de facto umowę o wolnym handlu (ECFA). Postrzegane zbliżenie do Chin komunistycznych doprowadziło jednak do silnej reakcji znacznej części tajwańskiego społeczeństwa. Obserwowany od dwóch dekad wzrost poczucia tożsamości tajwańskiej, kosztem chińskiej, przełożył się na silny ruch protestu wobec dalszego zacieśniania więzów z kontynentem. Jego najbardziej widocznym wyrazem była okupacja budynku parlamentu w Tajpej przez demonstrantów z tzw. ruchu stonecznika w 2014 r. Chociaż trudno o jednoznaczne oceny i prognozy to jednak warto się zastanowić czy wyborczy sukces DPP i wyraźny kryzys Partii Narodowej, postrzeganej jako partia jednych Chin - nie jest zapowiedzią trwałej zmiany na tajwańskiej scenie politycznej w stronę konsensusu na rzecz niezależności i samostanowienia. Naturalnie, ani DPP nie jest obecnie orędownikiem niepodległości, ani też KMT nie była partią unifikacji (Cole, 2017: 175-182). Zasadniczym problemem pozostaje jednak kwestia postrzegania tych zmian w Pekinie. Władze ChRL zareagowały na wybór Tsai Ing-Wen wyraźnym niezadowoleniem. 
Po inauguracji, w trakcie której nowa prezydent nie wyraziła jednoznacznego poparcia dla „konsensusu jednych Chin” ChRL zerwała półoficjalne relacje z rządem Tajwanu (Grossman, 2016). Chociaż póki co obie strony postępują ostrożnie i starają się nie destabilizować status quo, to jednak pojawia się zasadnicze pytanie - jak zareaguje ChRL jeśli władze dojdą do wniosku, iż na Tajwanie zdobywa dominację opcja samostanowienia/niepodległościowa, a czas nie gra już na korzyść ChRL i forsowanej polityki unifikacji? Można zakładać, iż polityka prezydenta Ma Ying-jeu rozbudziła wśród przywódców ChRL oczekiwania, iż w dłużej perspektywie Tajpej będzie zmierzało w stronę coraz bliższych relacji z kontynentem co stworzy klimat dla ewentualnego zjednoczenia. Wyraźny sukces opcji postrzeganej w Pekinie jako niepodległościowa oraz istotne osłabienie KMT mogą wywołać wrażenie, iż Tajwan wszedł na drogę samostanowienia i konieczne jest podjęcie zdecydowanych działań celem powstrzymania secesji.

\section{C) Wyrok w sprawie chińskich roszczeń na Morzu Południowochińskim}

12 lipca 2016 r. Stały Trybunał Arbitrażowy w Hadze wydał wyrok w sprawie wniesionej przez Filipiny odnośnie roszczeń i działań ChRL na Morzu Południowochińskim. Wyrok był miażdżący dla stanowiska ChRL odnośnie tego sporu. Trybunał uznał, iż argumentacja ChRL oparta na tytule historycznym nie ma uzasadnienia w prawie międzynarodowym (PCA Award, 2016: par. 278). Ponadto stwierdzono, iż chińskie działania na spornym terenie (jak rozbudowa raf $\mathrm{i}$ atoli czy ograniczanie dostępu Filipinom) są niezgodne $\mathrm{z}$ obowiązującym prawem międzynarodowym (PCA Award, 2016: par. 716, 814, 992, 993, 1043). Teoretycznie jest to bardzo doniosłe wydarzenie. Wyrok sądu międzynarodowego uznający działania stałego członka Rady Bezpieczeństwa ONZ za nielegalne jest niewątpliwie zjawiskiem unikatowym. Jednocześnie jednak, patrząc z perspektywy niecałego roku od tych wydarzeń, można zauważyć, iż pozycja głównych uczestników tego sporu nie uległa zasadniczej zmianie. ChRL w zasadzie odmówiła uznania wyroku i nadal go ignoruje. Filipiny, zwłaszcza po objęciu urzędu prezydenta przez Rodrigo Duterte, w zasadzie nie starają się egzekwować wyroku, ani nawet wykorzystać go jako poważnego argumentu dyplomatycznego. Pozycja ChRL na Morzu Południowochińskim nie uległa osłabieniu, wręcz przeciwnie, rozbudowa infrastruktury (w tym wojskowej) postępuje. Kwestii orzeczenia nie należy jednak bagatelizować. Rozstrzygnięcie to jest de facto potwierdzeniem klęski chińskiej strategii (retoryki?) ,,pokojowego wzrostu”, która odniosła w poprzedniej dekadzie realne sukcesy w zwiększaniu legitymacji chińskiej polityki w oczach państw regionu. Chociaż zdolność ChRL do kontroli coraz większych obszarów Morza Południowochińskiego rośnie, to jednocześnie akceptacja państw regionu dla polityki ChRL maleje. Prawdopodobnie największym sukcesem polityki zagranicznej Chin początku XXI wieku było przekonanie większości państw regionu, iż wzrost ich potęgi im nie zagraża, a współpraca z ChRL jest korzystniejsza od prób równoważenia jej potęgi. Jawnie agresywne działania władz w Pekinie na Morzu Południowochińskim, obecnie uznane za nielegalne przez kompetentny międzynarodowy organ sądowniczy, przyczyniły się do zwrotu szeregu państw ASEAN w stronę bliżej współpracy wojsko- 
wej z USA. Tym samym Chiny, zwiększając obszar kontrolowanego terytorium coraz bardziej antagonizują regionalnych partnerów i kierują ich w stronę USA.

\section{D) Wybory prezydenckie w USA}

Zwycięstwo Donalda Trumpa w wyborach prezydenckich 8 listopada 2016 r. stanie się prawdopodobnie jednym z najszerzej komentowanych i analizowanych wydarzeń politycznych tej dekady. Ograniczając się do efektów zmiany administracji dla regionu Azji Wschodniej należy skupić się trzech głównych punktach. Na samym wstępie należy podkreślić, iż rola USA w regionie Azji Wschodniej jest trudna do przecenienia. Jak już wcześniej wspomniano, państwo to jest głównym architektem i gwarantem obecnego ładu regionalnego na tym obszarze. Polityka zagraniczna i bezpieczeństwa administracji 45 prezydenta USA może zostać na tym etapie najlepiej określona jako in statu nascendi. Na tym etapie można jednak wskazać na trzy cechy istotne dla omawianego regionu. 1) wzrost nieprzewidywalności - do tej pory polityka USA była przewidywalna i raczej sprzyjała zachowaniu status quo. Obecnie istotną cechą jest nieprzewidywalność i zmienność, co poważnie utrudnia kalkulacje wszystkich pozostałych graczy; 2) pytania o stan amerykańskiego przywództwa w regionie - jednym z niewielu jednoznacznych ruchów podjętych przez nowego prezydenta było wycofanie USA z wynegocjowanego już Partnerstwa Trans-Pacyficznego - umowy o wolnym handlu zrzeszającej 12 państw basenu Pacyfiku. TPP miało być ekonomicznym filarem strategii zwrotu $k u$ Azji i stać się rdzeniem regionalnej integracji gospodarczej pod przywództwem USA. Wycofanie się Waszyngtonu z tej inicjatywy otwiera drogę dla alternatywnych propozycji wysuwanych przez Chiny (jak RCEP). Stawia to szersze pytanie, czy potencjalne wycofanie się USA z roli lidera regionalnych instytucji i współpracy może otworzyć pole dla przejęcia tej roli przez Chiny?; 3) niepewność polityki wobec ChRL - biorąc pod uwagę znaczną liczbę (często sprzecznych) deklaracji i posunięć można odnieść wrażenie, iż administracja prezydenta Trumpa słusznie postrzega ChRL jako najważniejszego aktora w regionie. Oczekiwania wobec relacji z ChRL skupiają się wokół wyrównania relacji gospodarczych. Nie brakuje jednak również posunięć co najmniej prowokacyjnych, jak chociażby (chwilowe) kwestionowanie polityki jednych Chin.

\section{E) Normalizacja polityki obronnej Japonii}

Zmiany zachodzące $\mathrm{w}$ japońskiej polityce obronnej mają charakter ewolucyjny i trudno byłoby wskazać konkretne wydarzenia 2016 r. jako naprawdę przełomowe. Nie zmienia to jednak faktu, iż stopniowe przekształcanie Japonii w normalnq potęgę militarną jest ważnym czynnikiem kształtującym międzynarodowe środowisko bezpieczeństwa Azji Wschodniej. Jesienią 2015 r. japoński parlament przyjął nowe ustawodawstwo umożliwiające udział Sił Samoobrony w obronie zbiorowej. Ta potencjalnie rewolucyjna zmiana może oznaczać de facto rewizję art. 9 japońskiej konstytucji bez jego zmiany de iure. Wpisuje się to w strategię proaktywnego wkładu 
w pokój, wyłożonej jeszcze w strategii bezpieczeństwa narodowego z 2014 r. (Japa$n$ 's Legislation, 2015; Short, 2015). Pierwszym praktycznym zastosowaniem nowych przepisów było rozszerzenie mandatu misji japońskiego kontyngentu w siłach pokojowych ONZ rozmieszczonych w Sudanie Południowym o możliwość użycia siły dla ochrony innego personelu misji (po raz pierwszy w historii udziału japońskich żołnierzy w siłach pokojowych ONZ) (Gady, 2016b). Przełomowy charakter tych wydarzeń niewątpliwie przyćmiła jednak decyzja z marca 2017 r. o wycofaniu kontyngentu po zakończeniu obecnej rotacji (Tatsumi, 2017). Pod koniec 2016 r. gabinet premiera Abe Shinzo przedstawił również projekt rekordowo wysokiego budżetu obronnego na 2017 r. (Panda, 2016). Natomiast w marcu 2017 r. premier ogłosił koniec polityki utrzymywania wydatków obronnych na poziomie nieprzekraczającym 1\% PKB (Wright, 2017). Jest to kolejny krok w swoistej taktyce salami demontażu systemu ograniczeń nałożonych na japońską politykę obronną w okresie powojennym. Próbując określić długoterminowy wpływ tych zmian na sytuację w regionie, należy uniknąć zarówno ich niedoceniania, jak i przeceniania. Niewątpliwie Japonia znajduje się na kursie prowadzącym do możliwości prowadzenia coraz bardziej niezależnej i zdecydowanej polityki bezpieczeństwa za pomocą instrumentów militarnych. Jednocześnie jednak za mocnymi deklaracjami rzadko podążają zdecydowane kroki. Mimo nowego ustawodawstwa Siły Samoobrony nadal dysponują bardzo ograniczonymi możliwościami prowadzenia działań bojowych poza sytuacją bezpośredniego ataku na Japonię. Należy jednak pamiętać o szerszym kontekście regionalnym tych zmian. Wzmacnianie potencjału obronnego Japonii jest w znacznym stopniu podyktowane wzrostem stanu i poczucia zagrożenia ze strony ChRL i KRL-D. Nie zaskakuje fakt, iż ChRL odnosi się do tego procesu bardzo krytycznie. Naprawdę interesujące jest natomiast to, iż inne państwa regionu, do tej pory podejrzliwe wobec zmian w japońskiej polityce bezpieczeństwa zaczynają powoli postrzegać je jako pozytywne. Przykładem może być (mocno opóźnione) ratyfikowanie porozumienia o wymianie informacji wywiadowczych między Japonią a Republiką Korei (Jaehan Park, Sangyoung Yun, 2016), nowy projekt współpracy obronnej Japonia-ASEAN (Parameswaran, 2016), czy rosnąca obecność Morskich Sił Samoobrony na Morzu Południowochińskim (LaGrone, 2017). Istotną zmianą jakościową (obok wzrostu potencjału Sił Samoobrony) jest zatem zmiana postrzegania Japonii przez inne państwa regionu jako państwa będącego potencjalnym sojusznikiem w sporach z Chinami.

\section{PERSPEKTYWY DALSZEJ EWOLUCJI MIĘDZYNARODOWEGO ŚRODOWISKA BEZPIECZEŃSTWA AZJI WSCHODNIEJ}

Próbując skonstruować prognozę dalszego rozwoju sytuacji bezpieczeństwa w omawianym regionie, wypada rozpocząć od zastrzeżenia, iż działania takie zawsze obarczone są istotnym ryzykiem. Biorąc to pod uwagę, zamiast kompletnych scenariuszy wskazać należy kilka czynników stabilizacji i destabilizacji międzynarodowego środowiska bezpieczeństwa Azji Wschodniej oraz przedstawić kilka uwag odnośnie nakreślonych wcześniej tendencji.

Za najistotniejsze czynniki stabilizujące sytuację w regionie należy uznać: 
A) współzależność gospodarczą - przywódcy większości państw regionu zdają sobie sprawę, iż Azja Wschodnia stała się jednym z centrów gospodarki światowej w bezprecedensowo krótkim czasie dzięki handlowi międzynarodowego i globalizacji gospodarczej. Dalszy rozwój społeczno-gospodarczy jest priorytetem dla niemal wszystkich państw tego obszaru. Rosnące napięcia polityczne, a już szczególnie perspektywa otwartego konfliktu zbrojnego grożą zakłóceniem złożonego regionalnego węzła inwestycji zagranicznych, transgranicznych sieci produkcyjnych oraz eksportu. Stanowi to istotny czynnik motywujący przywódców do łagodzenia napięć;

B) potrzeba wewnętrznej stabilności politycznej. Kwestia ta istotnie wiąże się z omówionymi powyżej zagadnieniami gospodarczymi. Wiele państw regionu przechodzi fazę istotnych przemian społeczno-gospodarczych i w konsekwencji również politycznych. W ChRL Komunistyczna Partia Chin próbuje utrzymać kontrolę nad dynamicznie zmieniającym się społeczeństwem, jednocześnie zarządzając zmianą gospodarki na usługową i w większym stopniu polegającą na popycie wewnętrznym (Emmott, 2015). Pasmo sukcesów premiera Abe Shinzo w Japonii od 2012 r. wynika głównie nie z poparcia dla polityki rewizji konstytucji i nacjonalizmu, a raczej z oczekiwań kompetentnego przywództwa w opanowaniu konsekwencji przedłużającej się stagnacji gospodarczej. Przykłady można mnożyć, jednak już te dotyczące czołowych potęg regionu pokazują, iż przywódcy, tak demokratyczni, jak i autokratyczni potrzebują w najbliższych latach raczej stabilnego otoczenia międzynarodowego sprzyjającego reformom wewnętrznym;

C) istniejące sojusze polityczno-militarne. Architektura sojuszy zbudowana jeszcze w czasie zimnej wojny obejmuje sieć dwustronnych sojuszy USA z państwami regionu oraz sojusz ChRL-KRL-D. Mimo możliwości uwikłania ich uczestników w konflikty, których bezpośrednimi stronami nie są, instytucje te jednak zdecydowanie stabilizują sytuację $\mathrm{w}$ regionie. Wynika to $\mathrm{z}$ faktu, iż czołowe mocarstwa (USA i ChRL) muszą brać pod uwagę, iż agresywne działania wobec mniejszych graczy mogą doprowadzić do starcia z ich sojusznikami, co w świetle pozostałych tendencji działa stabilizująco;

D) stan równowagi militarnej. Istotnym i długofalowym czynnikiem zmniejszającym prawdopodobieństwo otwartego konfliktu zbrojnego (choć zupełnie go nie eliminującym) jest sytuacja, którą można by określić mianem pata strategicznego. Autor rozumie przez to stan, w którym obie strony potencjalnego konfliktu uznają jego koszty (finansowe, ludzkie, polityczne) za zbyt wysokie, aby uznać decyzję o rozpoczęciu otwartych walk za racjonalną. W regionie Azji Wschodniej dotyczy to przede wszystkim relacji wzajemnego odstraszania USA-ChRL. W opinii autora potencjał nuklearny, cybernetyczny, kosmiczny (w tym przede wszystkim antysatelitarny) oraz konwencjonalny obu państw jest już na tyle znaczący, iż żadna ze stron nie ma realistycznych oczekiwań szybkiego i łatwego zwycięstwa w potencjalnej wojnie. Jest to zatem istotny czynnik stabilizujący międzynarodowe środowisko bezpieczeństwa regionu. Można postawić tezę, iż w przeciwieństwie do Europy 1914 r. (do której Azja Wschodnia jest często porównywana) decydenci polityczni i militarni mają świadomość, iż otwarty konflikt zbrojny jest opcją wielce ryzykowną, potencjalnie bardzo kosztowną i o nie- 
pewnych szansach powodzenia.

O destabilizacji sytuacji bezpieczeństwa w regionie decydują w istotnym stopniu następujące czynniki:

A) nastroje nacjonalistyczne. Zjawisko chińskiego nacjonalizmu jest przedmiotem żywego zainteresowania szeregu badaczy. Nie ulega wątpliwości, iż lata konsekwentnej edukacji patriotycznej przyczyniły się do wytworzenia masowego/ludowego nacjonalizmu jako istotnej siły społecznej w Chińskiej Republice Ludowej. Władze partyjno-państwowe naturalnie wykorzystują te nastroje instrumentalnie, jednak nie są w stanie nad nimi w pełni panować. W konsekwencji, decydenci muszą brać pod uwagę reakcję krajowej opinii publicznej przy planowaniu posunięć w polityce zagranicznej. Chociaż nacjonalizm chiński jest najbardziej widoczny w optyce medialnej i badawczej, to generalnie można zidentyfikować szerszy trend rosnącego poczucia własnej wartości i asertywności wśród elit oraz szerszych społeczeństw regionu. Nie w każdym przypadku można to określić mianem erupcji nacjonalizmu, jednak w szeregu państw Azji Wschodniej (Japonia, Korea Południowa, Wietnam etc.) można zauważyć większą świadomość silniejszej niż jeszcze kilka dekad temu pozycji międzynarodowej własnego państwa i rosnących wobec tego oczekiwań w zakresie ochrony istotnych interesów narodowych. Niższa tolerancja opinii publicznej dla (realnych lub jedynie postrzeganych) naruszeń własnych interesów narodowych przez państwa trzecie zmniejsza elastyczność prowadzenia polityki zagranicznej wielu państw regionu;

B) silne i mniej przewidywalne przywództwo. W ciagu kilku ostatnich lat w szeregu państw regionu można zauważyć tendencje do umocnienia osobistej pozycji politycznej szefów państw/rządów i w konsekwencji wykształcenie się bardziej spersonalizowanego stylu przywództwa. Za czołowy przykład uznaje się ChRL, gdzie Przewodniczący Xi Jinping skupił w swych rękach władzę na skalę niespotykaną w tym państwie od czasów Deng Xiaopinga. Jednocześnie osłabieniu (choć oczywiście nie zanikowi) uległa reguła kolektywnego kierownictwa (Huiyun Feng, Kai He, 2017; Chairman of, 2016). Zbliżone tendencje (choć naturalnie w innym kontekście ustrojowym i instytucjonalnym) można zaobserwować w Japonii, gdzie premier Abe Shinzo osobiście wyznacza kierunki działania rządu i partii rządzącej w stopniu większym niż jego poprzednicy (z wyjątkiem Koizumiego Junichirego). Spersonalizowane przywództwo polityczne jest wciąż w japońskiej polityce zjawiskiem względnie nowym, stąd pozycja premiera Abe w drugiej kadencji jego rządów w takim stopniu się wyróżnia. Skrajnym przypadkiem są Filipiny, gdzie wybrany w 2016 r. na urząd prezydenta Rodrigo Duterte dokonał istotnej korekty (jeżeli nie pełnego zwrotu) w polityce zagranicznej, dystansując się od USA i zbliżając do ChRL. Omawiany trend dotkną również Stanów Zjednoczonych. Specyfika i kierunek polityki zagranicznej prezydenta Donalda Trumpa jest przedmiotem niezliczonych analiz i komentarzy. Dość jednak wspomnieć, iż jeżeli miałaby się z nich wyłonić jedna wstępna konkluzja, to byłaby nią znaczna skłonność do nagłych i zaskakujących decyzji oraz silne oparcie procesu decyzyjnego na osobie prezydenta oraz kręgu jego najbliższych doradców. Sytuacja ta niesie ze sobą konsekwencje dla stabilności i kształtu stosunków międzynarodowych w regonie. Autor nie zamierza przeceniać roli jednostek w stosunku do czynników systemowych kształtujących stosunki międzynarodowe. Nie można jednak pominąć 
faktu, iż spersonalizowane przywództwo ułatwia zrywanie ciagłości w polityce zagranicznej i bezpieczeństwa oraz zwiększa jej nieprzewidywalność;

C) antagonizm na linii Rosja-Zachód. Obecne napięcia między Federacją Rosyjską a Stanami Zjednoczonymi (czy szerzej państwami Zachodu) wypływające z konfliktu ukraińskiego i rozszerzające się na konflikt syryjski nie rozgrywają się na obszarze Azji Wschodniej. Maja jednak potencjalnie istotne znaczenie dla układu sił i ewolucji sytuacji międzynarodowej na tym obszarze. Jak już wcześniej zaznaczono, międzynarodowe środowisko bezpieczeństwa Azji Wschodniej w coraz większym stopniu charakteryzuje dwubiegunowy antagonizm amerykańsko-chiński. Pozycja Rosji w tym układzie przez długi czas nie była w pełni określona. Chociaż FR i ChRL łączy wizja wielobiegunowego świata i niechęć do amerykańskiej promocji demokracji, to jednak wizja antyamerykańskiego sojuszu tych dwóch państw była mocno przedwczesna. Poziom strategicznego zaufania Rosji do ChRL jest ograniczony. FR była również otwarta na współpracę z konkurentami ChRL, chociażby sprzedając broń Indiom i Wietnamowi czy rozważając współpracę gospodarczą (w tym energetyczną) z Japonią. Tym samym Rosja przez długi czas pozostawała samodzielnym (choć niezbyt silnym) biegunem w polityce azjatyckiej. Obecna konfrontacja z Zachodem sprawia, iż Rosja jest skazana na bliższą współpracę z Chinami². Dowodem tego może być nasilenie współpracy gospodarczej (w tym rekordowy kontrakt na dostawy gazu ziemnego), wojskowotechnicznej (dostawy najnowszego uzbrojenia, jak systemy przeciwlotnicze S-400 czy myśliwce Su-35) oraz strategiczno-politycznej (np. wspólne manewry flot obu państw na Morzu Południowochińskim). Ujmując rzecz zwięźle - odcięcie Rosji od Zachodu umacnia dwubiegunowy układ sił i interesów w Azji Wschodniej.

Próbując dokonać prognozy dalszej ewolucji międzynarodowego środowiska bezpieczeństwa Azji Wschodniej, należy przede wszystkim zwrócić uwagę, iż jesteśmy obecnie świadkami końca niekwestionowanej dominacji USA i ustanowionego przez to państwo ładu w regionie. Dla zachowania precyzji należy jednak podkreślić, iż nie jest to (póki co) koniec amerykańskiej dominacji, a jedynie koniec okresu, w którym ład wprowadzony i podtrzymywany przez USA nie był poważnie kwestionowany przez pozostałych graczy $w$ regionie. W ostatnich latach polityka zagraniczna ChRL przeszła w fazę aktywną. Porzucając (przynajmniej częściowo) 28-znakową instrukcję Deng Xiaopinga ${ }^{3}$, ChRL zaczęła aktywnie promować swoją wizję ułożenia ładu regionalnego. Nie oznacza to oczywiście, iż należy się spodziewać rychłego zastąpienia USA przez Chiny w roli dominującego mocarstwa w Azji Wschodniej. Co więcej, ChRL nie kwestionuje całkowicie dotychczasowego Pax Americana. Domagaja się jedynie (lub aż) uznania ich rosnącej potęgi i poszanowania własnych żywotnych interesów (jak przetrwanie reżimu czy roszczenia terytorialne). Nie mniej działania ChRL zaczynają przypominać realną alternatywę dla elementów dotychczasowego ładu. Aktywność polityki chińskiej ma niejako dwa oblicza - pozytywne i negatywne (z punktu widzenia pozostałych państw). Po stronie pozytywnej Pekin proponuje zakrojoną na

${ }^{2}$ Szerzej o obecnym stanie stosunków chińsko-rosyjskich: Charap, Drennan, Noël, 2017.

3 „Spokojnie obserwować sytuację, zabezpieczyć nasze stanowisko, pewnie radzić sobie ze zmianami, ukrywać własne możliwości i czekać na stosowny moment, umiejętnie utrzymywać niski profil, unikać wychylania się, być pro aktywnym" (Yong Deng, 2008: 41). 
szeroką skalę i otwartą praktycznie dla wszystkich zainteresowanych współpracę gospodarczą (OBOR, AIIB), stwarzając alternatywę dla USA w obszarze zapewniania międzynarodowych ,dóbr publicznych”. Odbiór tych inicjatyw jest często pozytywny. $\mathrm{Z}$ drugiej strony, ChRL coraz bardziej zdecydowanie dochodzi swoich roszczeń terytorialnych (Morza Wschodnio- i Południowochińskie), a także „karze” państwa za działania, które postrzega jako godzące w jej żywotne interesy (np. rozmieszczenie systemu THAAD w Korei Południowej). To prowadzi do zasadniczej sprzeczności, która charakteryzuje obecną strategię polityki zagranicznej ChRL - pozytywne zachęty do udziału w chińskim ładzie (głównie w postaci inicjatyw współpracy gospodarczej) są w dużej mierze niwelowane przez czasami otwarcie agresywne posunięcia obliczone na zabezpieczenie wąsko rozumianych chińskich interesów bezpieczeństwa.

Próbując odpowiedzieć na pytanie: co wydarzy się dalej? można wstępnie odpowiedzieć, że ład regionalny z dużą dozą prawdopodobieństwa ulegnie przemianie. Będzie temu towarzyszył wzrost liczby i skali napięć oraz incydentów prowadzących być może do ostrzejszych kryzysów. Pozimnowojenny Pax Americana w Azji Wschodniej utrzymywał niejako pod kontrolą szereg poważnych i nierozstrzygniętych konfliktów. Obecnie, w nowych warunkach (wzrost potęgi ChRL, rosnąca asertywność graczy regionalnych, niepewność co do amerykańskiego przywództwa) konflikty te coraz wyraźniej zmierzają do zaognienia i postawienia sprawy ich finalnego rozstrzygnięcia. Jeżeli połączymy to z bardziej spersonalizowanym przywództwem oraz rosnącą (nie tylko w Azji) skłonnością do sięgania po instrumenty dyplomacji przymusu (w tym zbrojne) to możemy się spodziewać częstszych i poważniejszych kryzysów. Nie można jednak zapominać o istotnych siłach działających na rzecz stabilizacji (patrz wyżej). Sprawiają one, iż prognoza dla międzynarodowego środowiska bezpieczeństwa Azji Wschodniej nie jest jednoznacznie negatywna.

Podsumowując, należy uznać, iż w perspektywie krótkoterminowej (powiedzmy roku) można się spodziewać wzrostu napięcia, jednak ryzyko poważnej eskalacji jest stosunkowo niewielkie. Mocarstwa regionalne będą raczej starały się postępować umiarkowanie ostrożnie. Natomiast w perspektywie średnioterminowej (powiedzmy 5 lat) można sobie wyobrazić region coraz bardziej spolaryzowany (na linii ChRL-USA + sojusznicy) z narastającą rywalizacją o dominację. Nie musi to jednak prowadzić do otwartego konfliktu zbrojnego. Wiele będzie zależało od tego jak USA i ChRL ułożą swoje relacje, czy USA będą broniły zdecydowanie swego prymatu czy nie? Na ile władze ChRL będą skuteczne w przejęciu roli gwaranta regionalnych „dóbr publicznych”?

\section{BIBLIOGRAFIA}

2016 World population data sheet. With a special focus on human needs and sustainable resources (2016), Population Reference Bureau, http://www.prb.org/pdf16/prb-wpds2016-web-2016. $\operatorname{pdf}(10.05 .2017)$.

Brooks S. G., Wohlforth W. C. (2015), The Rise and Fall of the Great Powers in the Twenty-first Century: China's Rise and the Fate of America's Global Position, „International Security”, Vol. 40, No. 3.

By the rockets' red glare (2016), „The Economist”, 28.05.2016. 
Chairman of everything (2016), „The Economist”, 2.04.2016.

Charap S., Drennan J., Noël P. (2017), Russia and China: A New Model of Great-Power Relations, „Survival Global Politics and Strategy”, Vol. 59, No. 1.

China's Policies on Asia-Pacific Security Cooperation (2017), http://www.fmprc.gov.cn/mfa_eng/ zxxx_662805/t1429771.shtml (10.05.2017).

Clarke M. (2016), Beijing's March West: Opportunities and Challenges for China's Eurasian Pivot, „Orbis”, Vol. 60, No. 2.

Cole J. M. (2017), Convergence or Conflict in the Taiwan strait The illusion of peace?, London.

Crocker Ch. A. (2015), The Strategic Dilemma of a World Adrift, „Survival”, Vol. 57, No. 1.

Dargnat Ch. (2016), China's Shifting Geo-economic Strategy, „Survival: Global Politics and Strategy", Vol. 58, No.3.

Emmott B. (2015), China: It's the Politics, Stupid, „Survival Global Politics and Strategy”, Vol. 57, No. 6.

Fasslabend W. (2015), The Silk Road: a political marketing concept for world dominance, „European View", Vol. 14, No. 2.

Ferdinand P. (2016), Westward ho-the China dream and 'one belt, one road': Chinese foreign policy under Xi Jinping, „International Affairs”, Vol. 92, No. 4.

Gady F.-S. (2016a), South Korea to Add More Missiles Capable of Hitting All of North Korea, „The Diplomat", 19.08.2016, http://thediplomat.com/2016/08/south-korea-to-add-more-missilescapable-of-hitting-all-of-north-korea/ (10.05.2017).

Gady F.-S. (2016b), Japan's Military Deploys Abroad With New Rules of Engagement, „The Diplomat", 22.11.2016 (10.05.2017).

Gawlikowski K. (2004), Azja Wschodnia po drugiej wojnie światowej $i$ znaczenie przełomu lat 80. $i$ 90. XX w., w: Azja Wschodnia na przełomie XX i XXI wieku: przemiany polityczne i społeczne: studia i szkice, Tom 1, (red.) K. Gawlikowski, M. Ławacz, Warszawa.

Gross Domestic Product 2015 (2015), World Development Indicators database, World Bank, http:// databank.worldbank.org/data/download/GDP.pdf (10.05.2017).

Grossman D. (2016), A Bumpy Road Ahead for China-Taiwan Relations, "TheRANDBlog”, 22.09.2016, http://www.rand.org/blog/2016/09/a-bumpy-road-ahead-for-china-taiwan-relations.html (10.05.2017).

Haliżak E.(1999), Stosunki międzynarodowe w regionie Azji i Pacyfiku, Warszawa.

Heisbourg F. (2013), A Surprising Little War: First Lessons of Mali, „Survival”, Vol. 55, No. 2.

Huiyun Feng, Kai He (2017), China under Xi Jinping Operational code beliefs, foreign policy, and the rise of China, w: Chinese Foreign Policy Under Xi, (red.) Hoo Tiang Boon, London.

Jaehan Park, Sangyoung Yun (2016), Korea and Japan's Military Information Agreement: A Final Touch for the Pivot?, „The Diplomat”, 24.11.2016, http://thediplomat.com/2016/11/koreaand-japans-military-information-agreement-a-final-touch-for-the-pivot/ (10.05.2017).

Japan's Legislation for Peace and Security Seamless Responses for Peace and Security of Japan and the International Community (2015), Government of Japan, http://www.mofa.go.jp/ files/000143304.pdf, (10.05.2017).

Kim Sam (2017), A Timeline of North Korea's Missile Launches and Nuclear Detonations, „Bloomberg", 16.04.2017, https://www.bloomberg.com/politics/articles/2017-04-16/north-koreamissile-launches-nuclear-detonations-timeline (10.05.2017).

LaGrone S. (2017), Report: Japan's Largest Warship Heading to South China Sea, Will Train With U.S., Indian Navies, USNI News, 13.03.2017, https://news.usni.org/2017/03/13/report-japans-largest-warship-heading-south-china-sea (10.05.2017).

Macias A. (2016), 'Mr. Kim has missile lust, and he's not giving up': A timeline of North Korea's 
brazen missile tests so far in 2016, „Business Insider”, 29.10.2016, http://www.businessinsider.com/timeline-of-north-korea-tests-2016-10?IR=T/\#january-6-north-korea-conductsits-fourth-ever-nuclear-weapons-test-1 (10.05.2017).

Nationalism unleashed (2017), „The Economist”, 17.03.2017.

Our bulldozers, our rules (2016), „The Economist”, 2.07.2016.

Panda A. (2016), With Eye on China, North Korea, Japan's Abe Pursues Record Defense Budget, „The Diplomat”, 1.09.2016, http://thediplomat.com/2016/09/with-eye-on-china-north-korea-japans-abe-pursues-record-defense-budget/ (10.05.2017).

Panda A. (2017), 2017: Year of the North Korean Intercontinental Ballistic Missile?, „The Diplomat", 3.01.2017, http://thediplomat.com/2017/01/2017-year-of-the-north-korean-intercontinental-ballistic-missile/ (10.05.2017).

Parameswaran P. (2016), Japan Reveals First ASEAN Defense Initiative With 'Vientiane Vision', „The Diplomat”, 26.11.2016, http://thediplomat.com/2016/11/japan-reveals-first-asean-defense-initiative-with-vientiane-vision/ (10.05.2017).

PCA Award. Case n 2013-19 In the matter of the South China Sea arbitration before An Arbitral Tribunal constituted under annex vii to the 1982 United Nations Convention on the Law of the Sea between The Republic of the Philippines and The People's Republic of China (2016), The Hague, 12.07.2016, https://pca-cpa.org/wp-content/uploads/sites/175/2016/07/PH-CN20160712-Award.pdf (13.05.2017).

Resolution 2270 (2016) Adopted by the Security Council at its 7638th meeting, on 2 March 2016 (2016), S/RES/2270 (2016), http://www.un.org/en/ga/search/view_doc.asp?symbol=S/ RES/2270\%282016\%29 (13.05.2017).

Short M. (2015), Return of the Rising Sun? Japan's New Security Legislation and its Bearing on US Interests, „Georgetown Security Studies Review”, 5.11.2015, http:/georgetownsecuritystudiesreview.org/2015/11/05/return-of-the-rising-sun-japans-new-security-legislation-and-itsbearing-on-us-interests/ (10.05.2017).

Strategic Survey (2016), International Institute for Strategic Studies, London.

Tatsumi Yuki (2017), Japan Self-Defense Force Withdraws From South Sudan, „The Diplomat”, 8.03.2017, http://thediplomat.com/2017/03/japan-self-defense-force-withdraws-from-southsudan/ (10.05.2017).

Trends in international arms transfers 2016 (2017), SIPRI, https://www.sipri.org/sites/default/files/ Trends-in-international-arms-transfers-2016.pdf (10.05.2017).

Trends in world military expenditure 2016 (2017), SIPRI, https:/www.sipri.org/sites/default/files/ Trends-world-military-expenditure-2016.pdf (10.05.2017).

Wiśniewski R., Hensarling B. (2015), Power in 2025: A Global Ranking, „R/evolutions: Global Trends \& Regional Issues", Vol. 3, No. 1.

World Trade Statistical Review (2016), World Trade Organization, https://www.wto.org/english/ res_e/statis_e/wts2016_e/wts2016_e.pdf (10.05.2017).

Wright J. (2017), Abe Scraps Japan's 1 Percent GDP Defense Spending Cap, „The Diplomat”, 29.03.2017, http://thediplomat.com/2017/03/abe-scraps-japans-1-percent-gdp-defensespending-cap/ (10.05.2017).

Yong Deng (2008), China's Struggle for Status The Realignment of International Relations, Cambridge.

Zunyou Zhou (2016), China's Comprehensive Counter-Terrorism Law, „The Diplomat”, 23.01.2016, http://thediplomat.com/2016/01/chinas-comprehensive-counter-terrorism-law/ (10.05.2017). 


\title{
STRESZCZENIE
}

Celem artykułu jest analiza stanu międzynarodowego środowiska bezpieczeństwa regionu Azji Wschodniej oraz zasadniczych kierunków jego ewolucji w roku 2016. Autor identyfikuje kluczowe trendy długoterminowe kształtujące regionalny ład bezpieczeństwa omawianego obszaru. Umożliwia to określenie „stanu wyjściowego” regionu na początku analizowanego okresu, a także określenie swoistego „tła strategicznego”, w odniesieniu do którego należy rozpatrywać bieżące wydarzenia. Następnie przedstawiono kluczowe wydarzenia z obszaru bezpieczeństwa międzynarodowego, które zaszły w Azji Wschodniej w trakcie 2016 r. (oraz w pierwszych miesiącach 2017 r.) oraz ukazano je w nakreślonym kontekście strategicznym. Pozwala to na sformułowanie wstępnej oceny co do wpływu pojedynczych wydarzeń na międzynarodowe środowisko bezpieczeństwa regionu (stabilizujące, destabilizujące lub neutralne). W ostatnim etapie, na bazie dotychczasowych rozważań podjęto próbę prognozy dalszej ewolucji sytuacji bezpieczeństwa w Azji Wschodniej w perspektywie kolejnych 12-18 miesięcy.

Słowa kluczowe: Azja Wschodnia, Chiny, Tajwan, Morze Południowochińskie, Korea

\section{INTERNATIONAL SECURITY ENVIRONMENT OF EAST ASIA IN 2016. KEY DETERMINANTS AND DIRECTIONS OF FUTURE EVOLUTION}

\begin{abstract}
The aim of the article is to analyze the state of the international security environment of East Asia and main directions of its evolution in year 2016. The author identifies key long-term trends shaping the regional security order of the considered area. This builds the picture of the region at the beginning of the period under consideration and provides the ,strategic background" for current events. This introduction is followed by a presentation of key international security events which have taken place in East Asia during 2016 (and early months of 2017). These are being shown in the wider strategic context. On that basis a preliminary assessment of given event's influence on the regional international security environment can be given. Finally, the author proposes a prognosis of future evolution of the security situation in East Asia during the next $12-18$ months.
\end{abstract}

Keywords: East Asia, China, Taiwan, South China Sea, Korea 